\title{
Biofortification
}

\section{ANTIOXIDANT CONTENTS OF PEPPER Capsicum spp. FOR USE IN BIOFORTIFICATION}

\section{M.I. MAMEDOV, O.N. PISHNAYA, A.A. BAIKOV, V.F. PIVOVAROV, E.A. DZHOS, A.A. MATYKINA, M.S. GINS}

Federal Research Center for Vegetable Growing, Federal Agency of Scientific Organizations, 14, ul. Selektsionnaya, pos. VNIISSOK, Odintsovo Region, Moscow Province, 143080 Russia, e-mail mubaris-mamedov@yandex.ru (corresponding author)

ORCID:

Mamedov M.I. orcid.org/0000-0001-8974-6295

Pishnaya O.N. orcid.org/ 0000-0001-9744-2443

Baikov A.A. orcid.org/0000-0003-4393-7525

Pivovarov V.F. orcid.org/0000-0003-1350-5852

The authors declare no conflict of interests

Acknowlegdgements:

Supported in part by Russian Science Foundation (grant № 16-16-10022)

Received July 17, 2017

\section{Abstract}

Dzhos E.A. orcid.org/0000-0002-2216-0094

Matykina A.A. orcid.org/0000-0002-4352-7430

Gins M.S. orcid.org/0000-0001-5995-2696

Natural potential of bioactive compounds accumulated by plants is often not taken into account in particular breeding. Biofortification, the enrichment of basic food crops with essential vitamins and minerals using breeding, is one of the most notable recent innovations in agriculture. In this paper, we studied pigment composition with regard to the amount of carotenoids and their contribution to fruit coloration in 20 accessions of different species of genus Capsicum. Red and yellow pigment levels and their ratios detected in the study were indicative of the carotenoid composition in fruits of each species. Also the varieties differed significantly in the carotenoid accumulation. In temperate climate of Moscow region the highest amount of pigments was found in the sweet variety Shokoladnyi ( $C$. annuum; $0.536 \mathrm{mg} / \mathrm{g}$ ), and in the spice varieties Purpurnyi tigr ( $C$. annuum; $0.708 \mathrm{mg} / \mathrm{g}$ ), Kitaiskii fonarik (C. baccatum; $0,685 \mathrm{mg} / \mathrm{g}$ ), Ideya (C. annuum; $0.629 \mathrm{mg} / \mathrm{g}$ ) and Chudo Podmoskov'ya ( $C$. annuum; $0.628 \mathrm{mg} / \mathrm{g}$ ). The highest level of ascorbic acid was accumulated by chili pepper Ideya (C. annuum; $414 \mathrm{mg} \%$ ), Rozhdestvenskii buket (C. annuum $\times$ C. frutescens; $370 \mathrm{mg} \%$ ), Yubileinyi VNIISSOK ( $C$. annuum; $326 \mathrm{mg} \%$ ), and Ognennaya deva (C. chinense; $301 \mathrm{mg} \%$ ). The ascorbic acid content did not depend on fruit color and plant species. Among the sweet pepper varieties high total antioxidant content (TAC) was characteristic of hybrid $F_{1}$ Oranzhevoe naslazhdenie ( $C$. annuum). The maximum total antioxidant amounts, as milligram equivalents (MME) of gallic acid per g, were 2.82 for Rozhdestvenskii buket $(C$. annuum $\times C$. frutescens $), 2.65$ for Ognennaya deva ( $C$. chinense), 2.57 for Idea ( $C$. annuum), and 2.19 for Kitaiskii fonarik ( $C$. annuum). In assessment of thermostable antioxidants extracted with $80 \%$ ethanol at $60{ }^{\circ} \mathrm{C}$ it was shown that the unstable antioxidants, mainly ascorbic acid, averaged $16 \%$ of the total antioxidants. Rozhdestvensciy buket, Kitaiskii fonarik, Purpurnyi tigr, Ognennaya deva plants, additionally to antioxidants, can accumulate one of the strongest natural antioxidant, the capsaicin, which determines their hot taste. The capsaicin content of the studied chili peppers varied from 1.36 to $9.57 \mathrm{mg} / \mathrm{g}$ of dry weight. High contents of carotenoids, ascorbic acid and TAC combined with capsaicin at 8 to 9 score points increase the total antioxidant capacity of these samples.

Keywords: Capsicum annuum, Capsicum baccatum, Capsicum pubescens, Capsicum chinense, Capsicum frutescens, pigments, carotenoids, antioxidants, ascorbic acid, biofortification

The global burden of disability is estimated by DALY's (disability adjusted life years), which in medicine means the number of years lost, adjusted for the duration of disability. In 2000, 136 million years of healthy life was lost in Europe, including over 56 million years due to nutritional factors. Analysis using DALY's shows that in Europe the cause of almost $60 \%$ of diseases is high blood pressure, smoking, excessive alcohol consumption, high cholesterol, overweight, insufficient intake of fruits and vegetables and a sedentary lifestyle [1-4]. Four of 
these risk factors are closely related to nutrition. According to some researchers, the state of health of modern man is largely determined by the nature, completeness and structure of the diet [5], which must be balanced by the complex of nutrients necessary for the body to level out the increasing effect of stressors.

High grade food of plant origin, including vegetables, is deemed effective way to reducing the risk of many diseases associated with metabolic disorders. Biofortification, which is the enrichment of foods with essential vitamins and minerals through selection, has become one of the most notable innovations in plant breeding. Until now, there is practically no production of vegetables for functional purposes in Russia, and breeders often do not pay due attention to the natural potential of plant accumulation of bioactive compounds during breeding for qualitative traits.

Pepper, like many other vegetable crops, is the source of the most important biological components such as macro- and microelements, antioxidants and vitamin C. Peppers are rich in carotenoids, various acids, sugars, polyphenols, especially flavonoids, quercetin and luteolin. Pepper can be included into the dietary products category [6-9]. Capsaicinoids, another biologically active substance specific for the Capsicum genus, in small concentrations acts as a gastroprotective agent, and also has a local analgesic effect [10, 11]. Among the fatsoluble compounds present in peppers, carotenoids occupy a special place with their important role in the prevention of gastric ulcers, age-related macular degeneration and cataract, and stimulate the immune system [8]. All these compounds are included in the antioxidant pool. Consumption of pepper fruits reduces the risk of inflammation [12], cancer [13-15] and chronic non-infectious diseases, including cardiovascular, diabetes [16-18] and obesity [13, 14].

Coloring is one of the most important indicative parameters of quality for pepper fruits and products based on them. Four genes $\left(y, c_{1}, c_{2}, c l\right)$ with epistatic interaction control and about 20 carotenoids (yellow-red pigments) form the color of mature Capsicum genus fruits, but the way of carotenoid synthesis inheritance as well as genetics of color intensity is not fully understood. Capsanthin, capsorubin and cryptoxanthin are found only in the Capsicum genus and serve as effective free radical stabilizers. Red color of pepper fruits is determined by capsanthin, capsanthin-5,6-epoxide and capsorubin, yellow-orange color is due to zeaxanthin, $\beta$-carotene, $\beta$-cryptoxanthin, violaxanthin, antheraxanthin and cucurbitaxanthin A [19]. Capsanthin in mature red fruits amounts to more than $60 \%$ of the total carotenoids.

Genotype, environmental conditions (light, temperature, mineral nutrition, atmospheric composition) and agrotechnologies (e.g., ripeness at harvesting, irrigation system) affect the antioxidant status of the fruit [20]. There are conflicting data on the effect of heat treatment of vegetables in cooking in the literature 22], while other works evidence for its increase or preservation [23, 24].

In this paper, the comparative studies of the antioxidant status of fruits in varieties and species of both sweet and hot peppers were first associated with Capsicum spp. biofortification in a temperate climate conditions. It is established that the color of fruits and its intensity in some genotypes is determined by the sum of carotenoids, while in others is due to the presence of only one group of pigments. No direct relationship is observed between the total content of carotenoids, capsaicinoids and the antioxidant status of pepper fruits.

The purpose of our work is to reveal the peculiarities of the antioxidants accumulation in the organs of different pepper varieties and types in case of insufficient heat supply, to evaluate the contribution of the thermostable antioxidants to their total quantity and to identify forms promising for breeding.

Techniques. Four samples of sweet Capsicum annuum pepper and 16 
samples of hot peppers of different ecogeographical origin, belonging to $C$. annuum, $C$. baccatum, $C$. pubescens, $C$. chinense and $C$. frutescens species, were studied in unheated film greenhouses in the temperate climate zone (Moscow Region, 2015-2016). Plants were grown from May to October (the agrotechnology corresponded to the one that is generally accepted for film greenhouses). The experiments were arranged in four replications; the plots $\left(5 \mathrm{~m}^{2}\right.$ each) were randomized; a sample size per estimation was 20 plants. In order to minimize the influence of weather conditions, layering and other factors, the comparative evaluation was performed in one year, on the same plants, on the fruits of the same tier, at the same time.

In biochemical analyzes, plant material was milled in a homogenizer with the extractant. The total antioxidant capacity (TAC) was determined amperometric method [25], adapted for the determination of hydrophilic and lipophilic fractions. The result was expressed via gallic acid equivalents (mgequivalent GA/g). Ethyl alcohol of $80 \%$ [26, 27] or a mixture of acetone and ethyl alcohol (1:1 v/v) was used [29] when extracting. In case of using ethyl alcohol, the analysis was carried out in two ways. In the first one, the plant material milled in the solution was placed in test tubes with lids and heated at $60{ }^{\circ} \mathrm{C}$ in a water bath for $60 \mathrm{~min}$ [26]. In the second one, the heating stage was passed [27], as well as for the extraction with a mixture of acetone and ethyl alcohol. The homogenate was then centrifuged for $15 \mathrm{~min}$ at $10,000 \mathrm{~g}$ and $4{ }^{\circ} \mathrm{C}$. An aliquot of the supernatant was used to determine antioxidant concentrations, diluting, if necessary. The measurements were carried out on a Tsvet-Yauza-01-AA device (NPO Khimavtomatika, Russia) in a constant current mode.

The pigment content was determined spectrophotometrically. The samples were homogenized in acetone and left for 1 hour at $5{ }^{\circ} \mathrm{C}$ in the dark. The homogenate was centrifuged and the absorbance of the supernatant was measured. The approach applied had been proposed by Hornero-Mendez et al. [19]. It is based on the properties of chromophores of carotenoids, which allow grouping them into two isochromatic families - yellow and red pigments. The content of each isochromatic fraction $(\mathrm{mg} / \mathrm{ml})$ was calculated by the formulas:

$$
\begin{array}{r}
\text { Red pigments }=\frac{2,144 \mathrm{~A}_{508}-0,4033 \mathrm{~A}_{472}}{270,9}, \\
\text { Yellow pigments }=\frac{1,7243 \mathrm{~A}_{472}-2,4501 \mathrm{~A}_{508}}{270,9} \text {. }^{3}
\end{array}
$$

Concentration of deoxidized ascorbic acid was determined iodometrically by titration of the extracts with potassium iodate in the presence of potassium iodide and starch in an acidic solution [29]. The amount of dry matter was evaluated after drying in an oven to a constant absolutely dry mass for 2 days at a temperature of $85^{\circ} \mathrm{C}$.

Statistical data processing was carried out with Origin Pro 9.0 software (http://www.originlab.com/Origin). Mean $(X)$ and standard errors of mean $( \pm \mathrm{SE})$ were calculated.

Results. It is known that all representatives of the Capsicum genus accumulate the largest amount of capsanthin, capsorubin and cryptoxanthin in their fruits [19]. The analysis of the content of red and yellow pigments in the fruit testified to the originality of the quantitative content of carotenoids in each species. There were significant varietal differences in the accumulation of carotenoids. The content of red and yellow pigments determines not only the color of the fruit, but also the color intensity. In a hybrid of sweet pepper $F_{1}$ Oranzhevoe naslazhdenie with a rich orange color of the fruit, the yellow pigment level was 6.20 times higher than in red-colored, with the 0.16 ratio of red and yellow pigments; in the Zheltyi buket variety with a yellow color of the fruit, the excess was 1.34-fold with a quantitative pigment ratio of 0.75 (Table 1). It should be 
noted that the yellow or orange color of the fruit and intensity of coloration is determined not by the total amount of yellow pigments, but by the ratio of zeaxanthin, $\beta$-cryptoxanthin and $\beta$-carotene.

1. Fruit color, content of pigments and their ratio in pepper (Capsicum spp.) ( $X \pm$ SE, Moscow Province, 2015-2016)

\begin{tabular}{|c|c|c|c|c|c|c|}
\hline \multirow[b]{2}{*}{ Sample } & \multirow[b]{2}{*}{ Species } & \multirow[b]{2}{*}{$\begin{array}{l}\text { Color during the stage } \\
\text { of technological/bio- } \\
\text { logical ripeness }\end{array}$} & \multicolumn{3}{|c|}{ Carotenoids, mg/g } & \multirow[b]{2}{*}{$\begin{array}{l}\text { Yellow to red } \\
\text { pigments ratio }\end{array}$} \\
\hline & & & $\begin{array}{l}\text { yellow } \\
\text { pigments }\end{array}$ & $\begin{array}{l}\text { red } \\
\text { pigments }\end{array}$ & \begin{tabular}{|l|}
$\sum$ red and \\
yellow \\
pigments
\end{tabular} & \\
\hline \multicolumn{7}{|c|}{ Sweet pepper } \\
\hline $\begin{array}{l}\mathrm{F}_{1} \text { Oranzhevoe } \\
\text { naslazhdenie }\end{array}$ & C. аппиит & Green/orange & $0.169 \pm 0.008$ & $0.027 \pm 0.001$ & $0.196 \pm 0.010$ & $0.16 \pm 0.01$ \\
\hline$F_{1}$ Sibiryak & C. апnиuт & Dark green/red & $0.052 \pm 0.003$ & $0.081 \pm 0.004$ & $0.133 \pm 0.007$ & $1.56 \pm 0.08$ \\
\hline Zheltyi buket & C. аппиит & Dark green/yellow & $0.063 \pm 0.003$ & $0.047 \pm 0.002$ & $0.110 \pm 0.006$ & $0.75 \pm 0.04$ \\
\hline Shokoladnyi & C. аппиит & Dark green /brown & $0.205 \pm 0.010$ & $0.331 \pm 0.017$ & $0.536 \pm 0.027$ & $1.61 \pm 0.08$ \\
\hline $\begin{array}{l}\text { Rozhdestvenskii } \\
\text { buket }\end{array}$ & \multicolumn{2}{|c|}{$\begin{array}{l}\text { C. annuum } \times \mathrm{Green} / \mathrm{red} \\
\text { C. frutescens }\end{array}$} & $\begin{array}{l}\text { e p p e r } \\
0.212 \pm 0.011\end{array}$ & $0.235 \pm 0.012$ & $0.447 \pm 0.022$ & $1.11 \pm 0.06$ \\
\hline Samotsvet & \multicolumn{2}{|c|}{$\begin{array}{l}\text { C. annuum } \times \text { Violet/ } \\
\text { C. frutescens }\end{array}$} & $0.178 \pm 0.009$ & $0.240 \pm 0.012$ & $0.418 \pm 0.021$ & $1.35 \pm 0.07$ \\
\hline Ideya & C. аппиит & Light-green/yellow & $0.625 \pm 0.031$ & $<0.004$ & $0.629 \pm 0.031$ & $<0.01$ \\
\hline Rocoto & C. pubescens & Dark green/red & $0.263 \pm 0.013$ & $0.308 \pm 0.015$ & $0.571 \pm 0.029$ & $1.17 \pm 0.06$ \\
\hline Kitaiskii fonarik & C.baccatum & Light green/red & $0.240 \pm 0.012$ & $0.445 \pm 0.022$ & $0.685 \pm 0.034$ & $1.85 \pm 0.09$ \\
\hline Kolokolchik & C. chinense & Dark green/yellow & $0.318 \pm 0.016$ & $<0.001$ & $0.319 \pm 0.016$ & $<0.01$ \\
\hline \multicolumn{7}{|l|}{ Trinidad Scorpion } \\
\hline Chocolate & C. chinense & Black/brown & $0.088 \pm 0.004$ & $0.179=$ & $0.267 \pm 0.013$ & 0.10 \\
\hline Tsyganenok & C. аппиит & Black/black and pink & $0.012 \pm 0.001$ & $0.051 \pm 0.003$ & $0.063 \pm 0.003$ & $4.25 \pm 0.21$ \\
\hline Bhyt jolokia & \multicolumn{2}{|c|}{$\begin{array}{l}\text { C. chinense } \times \text { Light green/yellow } \\
\text { C. frutescens }\end{array}$} & $0.266 \pm 0.013$ & $<0.003$ & $0.269 \pm 0.013$ & $<0.01$ \\
\hline Purpurnyi tigr & C. апnиит & Dark violet/red & $0.267 \pm 0.013$ & $0.441 \pm 0.022$ & $0.708 \pm 0.035$ & $1.65 \pm 0.08$ \\
\hline Mech & C. апnиит & Red & $0.127 \pm 0.006$ & $0.196 \pm 0.010$ & $0.323 \pm 0.016$ & $1.54 \pm 0.08$ \\
\hline Mech & C. аппиит & Light green/yellow & $0.470 \pm 0.024$ & $<0.003$ & $0.473 \pm 0.024$ & $<0.01$ \\
\hline Chudo Podmos- & & & & & & \\
\hline $\begin{array}{l}\text { kovya } \\
\text { Yubileinyi }\end{array}$ & C. аппиит & Light green/red & $0.295 \pm 0.015$ & $0.333 \pm 0.017$ & $0.628 \pm 0.031$ & $1.13 \pm 0.06$ \\
\hline VNIISSOK & C. аппиит & Green & $0.093 \pm 0.005$ & $0.312 \pm 0.016$ & $0.405 \pm 0.020$ & $3.35 \pm 0.17$ \\
\hline Ognennaya deva & C. chinense & Green/red & $0.277 \pm 0.011$ & $0.354 \pm 0.018$ & $0.581 \pm 0.029$ & $1.56 \pm 0.08$ \\
\hline
\end{tabular}

During the phase of biological ripeness of fruits in most studied varieties, $\beta$-carotene amounted about $10 \%$ of total carotenoids. The bright red color of the $F_{1}$ Sibiryak hybrid was due to higher content of red pigments. The highest quantity of carotenoids among sweet pepper varieties was noted in Shokoladnyi with a brown skin and burgundy-red pericarp at biological ripeness (with yellow and red pigments 0.205 and $0.331 \mathrm{mg} / \mathrm{g}$, respectively). The ratio of red and yellow pigments in the Shokoladnyi variety was $1.61 . \mathrm{F}_{1}$ Sibiryak with a bright red color of the fruit showed 1.56. Apparently, the presence of a significant amount of yellow and red pigments in the fruit of Shokoladnyi variety in combination with proteins could cause the formation of a brown color. According to A.S.H. Ong et al. [30], pigments provide color from yellow to dark red, and in combination with proteins can give green and blue color.

Red pigments prevailed in all samples of hot pepper with red fruits at biological ripeness. The same trend was observed in Trinidad Scorpion Chocolate hot pepper: the ratio of red and yellow pigments was 2.03, but the color of the fruits at biological ripeness was brown. In Trinidad Dglahou with a red color of the fruit, the amount of yellow pigments was 1.5 times greater than that of the red ones, 0.119 and $0.077 \mathrm{mg} / \mathrm{g}$, respectively. In both forms, the fruits were in a dark violet almost black color at technical ripeness phase.

We found red pigments in sweet peppers $F_{1}$ Oranzhevoe naslazhdenie (orange fruits) and Zheltyi buket (yellow fruits), 13.7 and $42.7 \%$, respectively. This trend was not observed in the hot peppers. In all the hot peppers with yel- 
low fruit coloring (Ideya, Kolokolchik, Bhyt jolokia, Mech), only yellow pigments and traces of red pigments were found. The largest accumulation of pigments occurred in sweet paper Shokoladnyi $(0.536 \mathrm{mg} / \mathrm{g})$ and in hot papers Purpurnyi tigr $(0.708 \mathrm{mg} / \mathrm{g})$, Kitaiskii fonarik $(0.685 \mathrm{mg} / \mathrm{g})$, Ideya $(0.629 \mathrm{mg} / \mathrm{g})$, and Chudo Podmoskovya $(0.628 \mathrm{mg} / \mathrm{g})$.

2. Antioxidant accumulation in fruits of various peppers Capsicum spp. ( $X \pm \mathrm{SE}$, Moscow Region, 2015-2016)

\begin{tabular}{|c|c|c|c|c|c|c|}
\hline \multirow[b]{2}{*}{ Sample } & \multirow{2}{*}{$\begin{array}{l}\text { Pungency, } \\
\text { points. }\end{array}$} & \multicolumn{3}{|c|}{ CCA, mg-equivalent GA/g } & \multirow{2}{*}{$\begin{array}{l}\text { Ascorbic } \\
\text { acid, } \mathrm{mg} \%\end{array}$} & \multirow{2}{*}{$\begin{array}{l}\text { Dry } \\
\text { matter, \% }\end{array}$} \\
\hline & & $\begin{array}{l}\text { acetone:ethanol, } \\
1: 1 \mathrm{v} / \mathrm{v}\end{array}$ & $\begin{array}{l}\text { ethanol, } \\
80 \%\end{array}$ & \begin{tabular}{|l|} 
ethanol $80 \%$ \\
$60{ }^{\circ} \mathrm{C}, 60 \mathrm{~min}$
\end{tabular} & & \\
\hline \multicolumn{7}{|c|}{ Sweet pepper } \\
\hline $\begin{array}{l}\mathrm{F}_{1} \text { Oranzhevoe } \\
\text { naslazhdenie }\end{array}$ & 0 & $1.27 \pm 0.06$ & $1.25 \pm 0.06$ & $0.94 \pm 0.05$ & $246 \pm 17$ & $10.6 \pm 0.5$ \\
\hline$F_{1}$ Sibiryak & 0 & $1.15 \pm 0.06$ & $0.98 \pm 0.05$ & $0.78 \pm 0.04$ & $225 \pm 16$ & $9.2 \pm 0.5$ \\
\hline Zheltyi buket & 0 & $0.82 \pm 0.04$ & $0.85 \pm 0.04$ & $0.61 \pm 0.03$ & $225 \pm 16$ & $7.8 \pm 0.4$ \\
\hline \multirow[t]{2}{*}{ Shokoladnyi } & 0 & $1.18 \pm 0.06$ & $0.94 \pm 0.05$ & $0.69 \pm 0.03$ & $238 \pm 17$ & $9.5 \pm 0.5$ \\
\hline & & $\mathrm{H}$ ot & $\mathrm{p}$ e $\mathrm{p} p$ e $\mathrm{r}$ & & & \\
\hline Rozhdestvenskii buket & $7-8$ & $1.66 \pm 0.08$ & $2.82 \pm 0.14$ & $2.38 \pm 0.12$ & $370 \pm 26$ & $16.4 \pm 0.9$ \\
\hline Samotsvet & 8 & $0.88 \pm 0.04$ & $1.84 \pm 0.09$ & $1.34 \pm 0.07$ & $150 \pm 10$ & $17.3 \pm 0.9$ \\
\hline Ideya & $2-3$ & $2.17 \pm 0.11$ & $2.57 \pm 0.12$ & $2.06 \pm 0.10$ & $414 \pm 29$ & $15.5 \pm 0.8$ \\
\hline Rocoto & 10 & $0.90 \pm 0.05$ & $1.04 \pm 0.05$ & $0.76 \pm 0.04$ & $79 \pm 6$ & $14.2 \pm 0.7$ \\
\hline Kitaiskii fonarik & 2 & $0.81 \pm 0.04$ & $0.84 \pm 0.04$ & $0.61 \pm 0.03$ & $158 \pm 11$ & $19.9 \pm 0.9$ \\
\hline Kolokolchik & 9 & $1.44 \pm 0.07$ & $1.37 \pm 0.07$ & $1.19 \pm 0.06$ & $202 \pm 14$ & $13.1 \pm 0.7$ \\
\hline Trinidad Dglahou & 10 & $1.26 \pm 0.06$ & $1.17 \pm 0.06$ & $0.90 \pm 0.05$ & $176 \pm 12$ & $12.8 \pm 0.6$ \\
\hline \multicolumn{7}{|l|}{ Trinidad Scorpion } \\
\hline Chocolate & 10 & $1.01 \pm 0.05$ & $1.08 \pm 0.05$ & $0.83 \pm 0.04$ & $178 \pm 12$ & $12.2 \pm 0.6$ \\
\hline Tsyganenok & 2 & $0.96 \pm 0.05$ & $1.53 \pm 0.08$ & $1.29 \pm 0.06$ & $192 \pm 13$ & $12.0 \pm 0.6$ \\
\hline Bhyt jolokia & 10 & $0.87 \pm 0.04$ & $1.29 \pm 0.06$ & $0.99 \pm 0.05$ & $158 \pm 11$ & $12.0 \pm 0.6$ \\
\hline Purpurnyi tigr & 9 & $2.17 \pm 0.11$ & $2.19 \pm 0.11$ & $1.77 \pm 0.09$ & $216 \pm 15$ & $18.7 \pm 0.9$ \\
\hline Mech & 0,5 & $1.20 \pm 0.06$ & $1.45 \pm 0.07$ & $1.13 \pm 0.06$ & $220 \pm 15$ & $10.2 \pm 0.5$ \\
\hline Mech & 1 & $1.35 \pm 0.07$ & $1.81 \pm 0.09$ & $1.38 \pm 0.07$ & $299 \pm 21$ & $12.0 \pm 0.6$ \\
\hline Chudo Podmoskovya & 1,5 & $1.48 \pm 0.07$ & $1.67 \pm 0.08$ & $1.28 \pm 0.06$ & $299 \pm 21$ & $11.6 \pm 0.6$ \\
\hline Yubileinyi VNIISSOK & 3 & $1.58 \pm 0.09$ & $1.62 \pm 0.08$ & $1.30 \pm 0.07$ & $326 \pm 23$ & $17.8 \pm 0.9$ \\
\hline Ognennaya deva & 8 & $1.85 \pm 0.09$ & $2.65 \pm 0.13$ & $2.03 \pm 0.10$ & $301 \pm 21$ & $16.3 \pm 0.8$ \\
\hline
\end{tabular}

Vitamin $\mathrm{C}$ is an important intracellular antioxidant along with carotenoids, protecting the human body from both free radicals and peroxides [31]. Peppers are among the leaders of vegetable crops for vitamin $\mathrm{C}$ level. The highest amount of ascorbic acid was found in hot peppers Ideya (414 mg\%), Rozhdestvenskii buket (370 mg\%), Yubileinyi VNIISSOK (326 mg\%), and Ognennaya deva $(301 \mathrm{mg} \%)$. Note that the vitamin $\mathrm{C}$ level did not depend on species or fruit color. Among the members of different species there were varieties with both red and yellow fruits (Table 2). There were no significant differences in the indices depending on the extractant used. Only four hot pepper varieties, Rozhdestvenskii buket, Samotsvet, Tsyganenok, Ognennaya deva, showed the differences of 40-70\% in SSA depending on the extractant.

Among sweet peppers, $F_{1}$ Oranzhevoe naslazhdenie plants had high antioxidant values. The maximum sum of antioxidants among the hot peppers was in Rozhdestvenskii buket (2.82 mg-equivalent GA/g), Ognennaya deva (2.65 mgequivalent GA/g), Ideya (2.57 mg-equivalent GA/g) and Purpurnyi tigr (2.19 mg-equivalent $\mathrm{GA} / \mathrm{g}$ ). The value of TAC varied significantly, depending on the variety and species. The estimation of total antioxidant whole, given their cooperative action, allows isolating the genotypes rich in antioxidants to involve them breeding as a parental forms. Rozhdestvenskii buket, Kitaiskii fonarik, Purpurnyi tigr, and Ognennaya deva varieties accumulated more capsaicin, another strongest natural antioxidant which determined the burning taste of pepper fruit, than other samples. The level of capsaicin in the studied hot pepper samples varied between $1.36-9.57 \mathrm{mg} / \mathrm{g}$ dry weight [32]. High content of carotenoids, ascorbic 
acid, total antioxidants and capsaicinoids (8-9 point pungency) further strengthened the synergetic antioxidant effect.

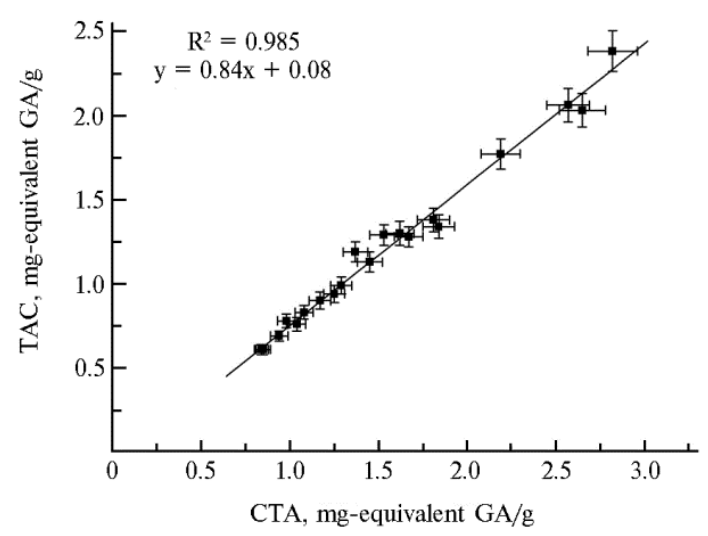

Contribution of thermostable antioxidants (CTA) to total antioxidant content (TAC) in pepper (Capsicum spp.) fruits of the studied samples (Moscow Province, 2015-2016).

The high content of dry matter (over $10 \%$ ) in fresh hot pepper fruits at biological ripeness (see Table 2) determines their use for multivitamin products with high antioxidant activity. Samotsvet, Kitaiskii fonarik, Purpurnyi tigr and Yubileinyi VNIISSOK peppers contain more than $17 \%$ dry matter, which allows quick drying fruits used for paprika powder and guarantees high quality of sauces and pasta.

Assessment of thermostable antioxidants to total antioxidant level when extracted with $80 \%$ ethanol and heated at $60{ }^{\circ} \mathrm{C}$ for 60 min showed that the contribution of the antioxidants unstable to thermal action, primarily ascorbic acid, was $16 \%$ on average (Fig.).

Thus, the obtained results allow us to conclude that the Shokoladnyi sweet pepper variety with brown fruits and the hot pepper varieties Ideya, Rocoto, Kitaiskii fonarik, Purpurnyi tigr, Chudo Podmoskovya, and Ognennaya deva are the leaders in pigments accumulation. In all the varieties, except Ideya, red and yellow pigments comparably contribute to pigment accumulation, while for Ideya variety there was a high pigment content solely due to the yellow fraction. Ideya, Chudo Podmoskovya, and Ognennaya deva varieties were characterized by an increased amount of deoxidized ascorbic acid. Ideya, Purpurnyi tigr, and Ognennaya deva varieties were characterized by an increased sum of low molecular weight antioxidants. So, Ideya and Ognennaya deva genotypes may serve as genetic sources of high antioxidant accumulation. The amount of red and yellow pigments, their total content, as well as the accumulation of ascorbic acid and capsaicinoids determine high antioxidant status of these samples, which can be the basis of biofortified foodstuff used both for functional products and in breeding programs.

\section{REFEREN C ES}

1. M u rray C.J. Rethinking DALYs. In: The global burden of disease. Global burden of disease and injury series. C.J. Murray, A.D. Lopez (eds.). Cambridge, Harvard University Press, 1996: 1-98.

2. Murray C.J., L o p e z A.D. Global mortality, disability, and the contribution of risk factors: Global Burden of Disease Study. Lancet, 1997, 349(9063): 1436-1442 (doi: 10.1016/S01406736(96)07495-8).

3. GBD 2015 D A LYs and HALE Collaborators. Global, regional, and national disability-adjusted life-years (DALYs) for 315 diseases and injuries and healthy life expectancy (HALE), 1990-2015: a systematic analysis for the Global Burden of Disease Study 2015. Lancet, 2016, 388(10053): 1603-1658 (doi: 10.1016/S0140-6736(16)31460-X).

4. M u r ray C.J., Lo pe z A.D. Regional patterns of disability-free life expectancy and disability-adjusted life expectancy. Global Burden of Disease Study. Lancet, 1997, 349(9062): 13471352 (doi: 10.1016/S0140-6736(96)07494-6).

5. Kny a z e v V.A., Sukh a nov V.P., Tut e ly a n V.A. Pravil'noe pitanie. Biodobavki, kotorye vam neobkhodimy [Proper food. Bioadditives you need]. Moscow, 1998 (in Russ.).

6. Guil-Guerrero J.L., Martinez-Guirado C., Rebolloso-Fuentes M., Carrique - Pére z A. Nutrient composition and antioxidant activity of 10 pepper (Capsicum annuum) varieties. Eur. Food Res. Technol., 2006, 224: 1-9 (doi: 10.1007/s00217-006-0281-5). 
7. Topuz A., Ozde mir F. Assessment of carotenoids. Capsaicinoids and ascorbic acid composition of some selected pepper cultivars (Capsicum annuum L.) grown in Turkey. J. Food Compos. Anal., 2007, 20: 596-602 (doi: 10.1016/j.jfca.2007.03.007).

8. Marín A., Ferreres F., To más-B a rberán F.A., Gil M.I. Characterization and quantitation of antioxidant constituents of sweet pepper (Capsicum annuum L.). J. Agr. Food Chem., 2004, 52: 3861-3869 (doi: 10.1021/jf0497915).

9. Alvarez-Parrilla E., de la Rosa L.A., Amarowicz R., Shahidi F. Antioxidant activity of fresh and processed Jalapeno and Serrano peppers. J. Agr. Food Chem., 2010, 59: 163-173 (doi: 10.1021/jf103434u).

10. Korkutat a N.F., Kava Z A.A. Comparative study of ascorbic acid and capsaicinoids contents in red hot peppers (Capsicum annum L.) grown in Southeastern Anatolia Region. Int. J. Food Prop., 2015, 18: $725-734$ (doi: 10.1080/10942912.2013.850507).

11. Mózsik G., S z o lcs a ny i J., Rá c z I. Gastroprotection induced by capsaicin in healthy human subjects. World J. Gastroenterod., 2005, 11(33): 5180-5184.

12. Zimme r A.R., L e o n a rdi B., M i ron D., Schapoval E., Olive ira J.R., G o s m a n G. Antioxidant and anti-inflammatory properties of Capsicum baccatum: from traditional use to scientific approach. J. Ethnopharmacol., 2012, 139(1): 228-233 (doi: 10.1016/j.jep.2011.11.005).

13. M eghvansi M.K., Siddiqui S., Khan M.H., Gupta V.K., Vairale M.G., G o g o i H.K., S i ngh L. Naga chilli: a potential source of capsaicinoids with broadspectrum ethnopharmacological applications. J. Ethnopharmacol., 2010, 132(1): 1-14 (doi: 10.1016/j.jep.2010.08.034).

14. Lu o X.J., Peng J., Li Y.J. Recent advances in the study on capsaicinoids and capsinoids. Eur. J. Pharmacol., 2011, 650: 1-7 (doi: 10.1016/j.ejphar.2010.09.074).

15. J e o ng W.Y., J in J.S., Cho Y.A., Le e J.H., Park S., J e ong S.W., Ki m Y.-H., Li m C.-S., E 1 - At y A.M.A., K i m G.-S., L e e S.J., Sh i m J.-H., Sh in S.C. Determination of polyphenols in three Capsicum annuum L. (bell pepper) varieties using highperformance liquid chromatography-tandem mass spectrometry: Their contribution to overall antioxidant and anticancer activity. Journal of Separation Science, 2011, 34: 2967-2974 (doi: 10.1002/jssc.201100524).

16. Ahuja K.D., Roberts on I.K., Geraghty D.P., B a 11 M.J. Effects of chili consumption on postprandial glucose, insulin, and energy metabolism. Am. J. Clin. Nutr., 2006, 84(1): 63-69.

17. Tundis R., Loizzo M.R., Menichini F., Bonesi M., Conforti F., Stat ti G., De Luca D., de Cindio B., Menichini F. Comparative study on the chemical composition, antioxidant properties and hypoglycaemic activities of two Capsicum annuum L. cultivars (Acuminatum small and Cerasiferum). Plant Food for Human Nutrition, 2011, 66(3): 261-269 (doi: 10.1007/s11130-011-0248-y).

18. Chaiyasit K., Khovidhunkit W., Wittayale rtpanya S. Pharmacokinetic and the effect of capsaicin in Capsicum frutescens on decreasing plasma glucose level. Journal of the Medical Association of Thailand, 2009, 92(1): 108-113.

19. Hornero-M endez D., Minguez-Mosquera M.I. Rapid spectrophotometric determination of red and yellow isochromic fractions in paprika and red pepper oleoresins. $J$. Agric. Food Chem., 2001, 49: 3584-3588 (doi: 10.1021/jf0104001).

20. Navarro J.M., Flores P., Garrido C., Martinez V. Changes in the contents of antioxidant compounds in pepper fruits at different ripening stages, as affected by salinity. Food Chem., 2006, 96: 66-73 (doi: 10.1016/j.foodchem.2005.01.057).

21. I s m a i 1 A., M a r j a $n$ Z. M., F o o ng C.W. Total antioxidant activity and phenolic content in selected vegetables. Food Chem., 2004, 87: 581-586 (doi: 10.1016/j.foodchem.2004.01.010).

22. $\mathrm{Zhang}$ D., $\mathrm{Ham}$ a u z $\mathrm{h}$. Phenolics, ascorbic acid, carotenoids and antioxidant activity of brocolli and their changes during conventional and microwave cooking. Food Chem., 2004, 88: 503-509 (doi: 10.1016/j.foodchem.2004.01.065).

23. G a hle r S., O t t o K., B o h m V. Alterations of vitamin C, total phenolics, and antioxidant capacity as affected by processing tomatoes to different products. J. Agric. Food Chem., 2003, 51: 7962-7968 (doi: 10.1021/jf034743q).

24. Turkmen N., S a ri F., Velioglu Y.S. The effect of cooking methods on total phenolics and antioxidant activity of selected green vegetables. Food Chem., 2005, 93: 713-718 (doi: 10.1016/j.foodchem.2004.12.038).

25. Gins M.S., Gins V.K., Baikov A.A., Romanova E.V., Kononkov P.F., To r res M.K., La p o O.A. Metodika analiza summarnogo soderzhaniya antioksidantov $v$ listovykh $i$ listostebel'nykh ovoshchnykh kul'turakh [Analysis of total antioxidants in leaf and leaf stem vegetables]. Moscow, 2013 (in Russ.).

26. De e pa N., Ka u r C., S ingh B., Kapoor H. Antioxidant activity in some red sweet pepper cultivars. J. Food Compos. Anal., 2006, 19: 572-578 (doi: 10.1016/j.jfca.2005.03.005).

27. Zhu ang Y., Che n L., Sun L., Ca o J. Bioactive characteristics and antioxidant activities 
of nine peppers. J. Funct. Foods, 2012, 4: 331-338 (doi: 10.1016/j.jff.2012.01.001).

28. Fox A.J., D e 1 Pozo D., L e e J.H., S a rge nt S.A., T a lc ott S.T. Ripening-induced chemical and antioxidant changes in bell peppers as affected by harvest maturity and postharvest ethylene exposure. HortScience, 2005, 40(3): 732-736.

29. S a p o zhnik ova E.V., D o rofe e va L.S. Konservnaya $i$ ovoshchesushil'naya promyshlennost', 1966, 5: 29-31 (in Russ.).

30. Ong A.S.H., Te e E.S. Natural sources of carotenoids from plants and oils. Methods Enzymol., 1992, 213: 142-167 (doi: 10.1016/0076-6879(92)13118-H).

31. Y u B.P. Cellular defenses against damage from reactive oxygen species. Physiol. Rev., 1994, 74: 139-162.

32. M a medov M.I., Pys haya O.N., Dzhos E.A., Nadezhkin S.M., Golubkina N.A., M a y u k i n a A.A. Niva Povolzh'ya, 2016, 3(40): 60-67 (in Russ.). 